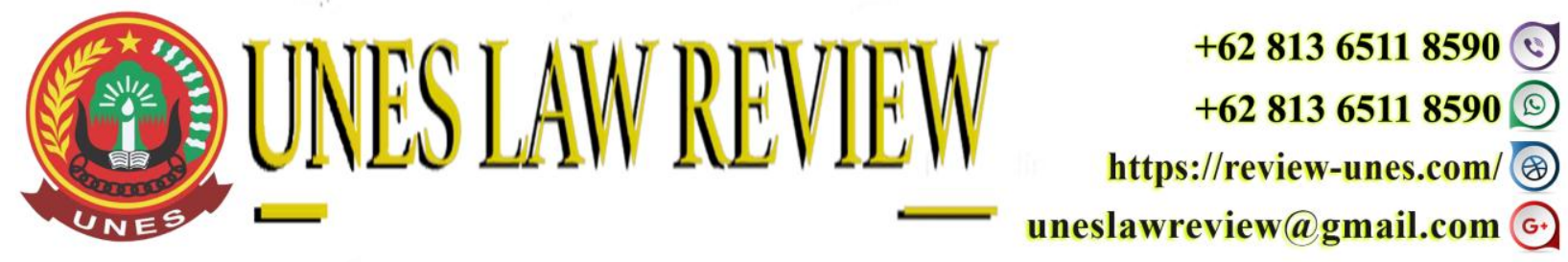

DOI: https://doi.org/10.31933/unesrev.v3i4

Diterima: 20/07/2021, Diperbaiki: 27/07/2021, Diterbitkan: 01/08/2021

\title{
KEWENANGAN CAMAT DALAM PEMBERDAYAAN PEMERINTAH NAGARI DI KECAMATAN SULIKI KABUPATEN LIMA PULUH KOTA
}

\author{
Ricky Edwar', Otong Rosadi ${ }^{2}$ \\ 1) Program Magister Ilmu Hukum, Fakultas Hukum, Universitas Ekasakti, Padang, Indonesia. \\ Email: rickyedward1732011@gmail.com \\ 2) Program Magister Ilmu Hukum, Fakultas Hukum, Universitas Ekasakti, Padang, Indonesia. \\ Email: otongrosadi@unespadang.ac.id
}

Corresponding Author: Ricky Edwar

\section{ABSTRACT}

Law Law Number 23 of 2014 concerning Regional Government mandates the Regency Regional Government to provide guidance and empowerment to the Village/Nagari Government through the Regional Apparatus/Camat organization. Article 226 paragraph (1) of Law Number 23 of 2014 concerning Regional Government states that in addition to carrying out the tasks as referred to in Article 25 paragraph (1), the Camat is delegated part of the authority of the Regent/Mayor to carry out some government affairs which are the authority of the Regency/City area. This research is an analytical descriptive study, with a normative juridical approach as the main approach and an empirical juridical approach as a supporter of the main approach. The data collected is secondary data and primary data. Data collection techniques with field studies through interviews for primary data and literature study for secondary data. The data obtained were analyzed qualitatively and presented in descriptive analytical form. Based on the results of the research and discussion, it can be concluded that Law Number 23 of 2014 concerning Regional Government, Government Regulation Number 17 of 2018 concerning Districts and Fifty Cities Regent Regulation Number 72 of 2016 concerning the Position of Organizational Structure, Duties and Functions as well as Subdistrict Work Procedures has set out in detail the duties and authorities of the Camat in empowering the Nagari government. However, the fact is that the development, empowerment and supervision of nagari are mostly carried out by sectoral institutions/services. This of course will indirectly lead to a reduction in the Camat's authority in carrying out activities, especially those involving the Nagari government. Due to the span of control that is too far away, the implementation of tasks in the sub-district and nagari is ineffective and inefficient. The obstacles faced by the Camat in the process of empowering the nagari government are the limited and lack of clarity of authority which causes the budget to not be allocated to empower the nagari government and the lack of coordination between the subdistrict government and the nagari government. The efforts made by the Camat are still carrying out their duties in accordance with the Regent of Fifty Cities Regulation Number 72 of 2016 
concerning 2016 concerning the Position of the Organizational Structure, Duties and Functions as well as Subdistrict Work Procedures.

Keywords: Authority, Camat, Empowerment, Nagari Pemerintah Government

\begin{abstract}
ABSTRAK
Undang-Undang Nomor 23 tahun 2014 tentang Pemerintahan Daerah mengamanatkan kepada Pemerintah Daerah Kabupaten untuk melakukan pembinaan dan pemberdayaan kepada Pemerintah Desa/Nagari melalui organisasi Perangkat Daerah/Camat. Pasal 226 ayat (1) Undang Undang Nomor 23 Tahun 2014 tentang Pemerintah Daerah menyatakan bahwa selain melaksanakan tugas sebagaimana dimaksud dalam pasal 25 ayat (1) Camat mendapatkan pelimpahan sebagian kewenangan Bupati/Walikota untuk melaksanakan sebagian urusan pemerintahan yang menjadi kewenangan daerah Kabupaten/Kota. Penelitian ini merupakan penelitian deskriptif analitis, dengan pendekatan yuridis normatif sebagai pendekatan utama dan yuridis empiris sebagai pendukung pendekatan utama. Adapun data yang dikumpulkan adalah data sekunder dan data primer. Teknik pengumpulan data dengan studi lapangan melalui wawancara untuk data primer dan studi kepustakaan untuk data sekunder. Data yang diperoleh dianalisi secara kualitatif dan disajikan dalam bentuk deskriptif analitis. Berdasarkan hasil penelitian dan pembahasan dapat ditarik kesimpulan bahwa Undang-Undang Nomor 23 Tahun 2014 tentang Pemerintahan Daerah, Peraturan Pemerintah Nomor 17 tahun 2018 tentang Kecamatan serta Peraturan Bupati Lima Puluh Kota Nomor 72 Tahun 2016 tentang Kedudukan Susunan Organisasi, Tugas dan Fungsi serta Tata Kerja kecamatan telah mengatur secara rinci tugas dan kewenangan Camat dalam pemberdayaan pemerintahan Nagari. Namun faktanya pembinaan, pemberdayaan serta pengawasan nagari lebih banyak dilakukan oleh lembaga sektoral/Dinas. Hal ini tentu secara tidak langsung akan mengakibatkan berkurangnya kewenangan Camat dalam melaksanakan kegiatan terutama yang menyangkut pemerintahan Nagari. Akibat rentang kendali yang terlalu jauh menyebabkan tidak efektif dan efisiennya pelaksanaan tugas di Kecamatan maupun di nagari. Hambatan yang dihadapi Camat dalam proses pemberdayaan pemerintahan nagari adalah terbatas dan kurang jelasnya kewenangan yang menyebabkan tidak teralokasinya anggaran guna memberdayakan pemerintahan nagari serta kurangnya koordinasi antara Pemerintah Kecamatan dengan Pemerintah Nagari. Upaya yang dilakukan Camat adalah tetap melaksanakan tugas sesuai dengan Peraturan Bupati Lima Puluh Kota Nomor 72 Tahun 2016 tentang 2016 tentang Kedudukan Susunan Organisasi, Tugas dan Fungsi serta Tata Kerja Kecamatan.
\end{abstract}

Kata Kunci: Kewenangan, Camat, Pemberdayaan, Pemerintah Nagari

\title{
PENDAHULUAN
}

Lahirnya Undang-undang Nomor 23 Tahun 2014 tentang Pemerintahan Daerah adalah upaya untuk mengatur hubungan antar jenjang pemerintahan dan pembagian urusan antar tingkat pemerintahan menjadi lebih baik. Berdasarkan konsep negara hukum kesejahteraan, secara umum tujuan negara adalah untuk menciptakan kesejahteraan, menciptakan ketertiban dan keamanan, dan memberikan kebahagiaan lahir dan bathin, maupun materil dan immateriil (Hufron dan Sofyan Hadi, 2015:39). Pemerintah mulai dari Presiden, Gubernur, Bupati/Walikota, Camat sampai Kepala Desa melakukan tugas negara untuk kesejahteraan. 
Dalam kontek ini Camat sebagai kepala organisasi perangkat daerah adalah pelaksana teknis dari kewenangan yang diberikan undang-undang dan kepala daerah untuk melayani masyarakat, sehingga Camat memiliki legitimasi dalam bertindak untuk melaksanakan tugas dan kewajibannya.

Kewenangan bersifat atributif yang dimiliki Camat adalah tugas umum pemerintahan, meliputi:

1. Mengkoordinasikan kegiatan pemberdayaan masyarakat

2. Mengkoordinasikan upaya penyelenggaraan ketenteraman dan ketertiban umum

3. Mengkoordinasikan penerapan dan penegakan peraturan daerah dan peraturan Kepala Daerah

4. Mengkoordinasikan pemeliharan sarana dan prasarana pelayanan umum

5. Mengkoordinasikan penyelenggaraan kegiatan pemerintahan yang dilakukan oleh perangkat daerah di Kecamatan

6. Membina dan mengawasi penyelenggaraan kegiatan desa dan/atau kelurahan

7. Melaksanakan urusan yang menjadi kewenangan Kabupaten/kota yang tidak dilaksanakan oleh unit kerja perangkat daerah kabupaten/kota yang dan di Kecamatan

8. Melaksanakan tugas lain sesuai dengan ketentuan peraturan perundang-undangan

Pasal 226 ayat (1) Undang Undang Nomor 23 tahun 2014 tentang Pemerintahan Daerah menyatakan bahwa selain melaksanakan tugas sebagaimana dimaksud dalam Pasal 225 ayat (1) Camat mendapatkan pelimpahan sebagian kewenangan Bupati/Walikota untuk melaksanakan sebagian urusan pemerintahan yang menjadi kewenangan daerah kabupaten/kota. Dengan berlakunya Undang Undang Nomor 6 Tahun 2014 tentang Desa, serta menguatnya peran dan otonomi desa/nagari telah menggeser kedudukan dan peran Kecamatan, sehingga Kecamatan tidak lagi bisa berfungsi sebagai atasan dari pemerintahan desa/nagari. Kecamatan berubah menjadi perangkat daerah sehingga secara tidak langsung berkewajiban untuk ikut melaksanakan sebagian tugas/kewenangan kabupaten/kota. Untuk itu diperlukan adanya pendelegasian wewenang kepada Camat . Disini Kecamatan yang masih bercirikan organisasi kewilayahan, justru diberi kewenangan yang bersifat sektoral. Dilema timbul, apakah Kecamatan perlu atau tidak diberikan kewenangan subtantif dengan potensi akan timbul benturan dengan lembagalembaga sektoral. Disisi lain selain melaksanakan kewenangan subtantif (yang diatur dalam peraturan daerah) dinas juga dapat menerima pelimpahan kewenangan dari Bupati/Walikota melalui surat keputusan.

Jika konsisten dengan jenis dan fungsi Kecamatan sebagai lembaga kewilayahan (dibatasi oleh batas geografis dan administratif), maka perlu dipertimbangkan kemungkinan Kecamatan hanya menyelenggarakan kewenangan tugas-tugas bidang pemerintahan umum. Fungsi Kecamatan sebagai pelaksana tugas pemerintahan umum telah diakomodir dalam Keputusan Menteri Dalam Negeri Nomor 158 Tahun 2004 tentang Pedoman Organisasi Kecamatan. Hal ini terlihat dari pengaturan dua seksi limitatif (dinyatakan secara wajib dalam peraturan perundangan) yakni seksi pemerintahan dan seksi keamanan dan ketertiban. Kedua seksi ini secara subtantif termasuk kategori kewenangan bidang pemerintahan umum saja. Hanya saja 
kalau Kecamatan diarahkan untuk menjalankan pemerintahan umum, maka ini tidak sejalan dengan ketentuan Pasal 225 ayat (1) Undang- undang Nomor 23 tahun 2014 yang menyatakan Camat mendapatkan pelimpahan sebagian kewenangan Bupati/Walikota untuk melaksanakan sebagian urusan pemerintahan yang menjadi kewenangan daerah kabupaten/kota sesuai dengan karekteristik wilayah. Dengan kata lain, Undang-undang ini cenderung memerintahkan Kecamatan untuk ikut serta menyelenggarakan kewenangan substantif/material.

Satuan-satuan pemerintahan otonomi yang mandiri dan demokratis juga akan lebih mendekatkan pemerintahan kepada rakyat sehingga berbagai kepentingan rakyat yang berbeda beda dapat dilayani secara wajar (Bagir Manan, 2005:25). Kecamatan adalah organisasi yang paling depan berhadapan dengan masyarakat, sudah selayaknyalah organisasi ini mendapat perhatian yang jauh lebih baik dengan cara memberdayakan pemerintahan Kecamatan. Dalam upaya meningkatkan peran Kecamatan, memperpendek birokrasi dan memudahkan pelayanan kepada masyarakat di era otonomi daerah, maka pemerintah kabupaten dituntut untuk dapat memberi kewenangan-kewenangan yang lebih banyak terhadap pemerintahan Kecamatan.

Di Sumatera Barat dengan semakin menguatnya otonomi nagari sesuai dengan amanat Undang-undang Nomor 6 Tahun 2014 Tentang Desa, saat ini banyak kewenangan yang telah diserahkan kepada nagari. Dengan berlakunya Undang-undang Nomor 23 Tahun 2014 dan Undang-undang Nomor 6 Tahun 2014, telah menggeser peran dan kedudukan Kecamatan, sehingga Kecamatan tidak lagi berfungsi sebagai atasan dari pemerintahan Desa/Nagari. Kedudukan desa pada Undang-undang ini telah menempatkan kedudukan pemerintahan Nagari pada saat ini terhadap pemerintahan Kecamatan adalah independent dan koordinat, keadaannya menjadi berbeda, terjadi perubahan yang sangat signifikan dalam hubungan antara pemerintahan Kecamatan dengan Nagari. Dengan menguatnya peran Nagari dan adanya kecendrungan pemerintah daerah lebih memilih Nagari ketimbang Kecamatan untuk melaksanakan urusanurusan pemerintahan di daerah. Fenomena ini memperlihatkan berkurangnya peranan Kecamatan dalam keikutsertaannya dalam penyelenggaraan pemerintahan dalam era otonomi daerah .

Pemerintahan nagari di Kecamatan Suliki yang terdiri dari 6 (enam) Nagari dalam pelaksanaan tugas kewilayahan, pemerintahan dan pemberdayaan mengalami kesulitan dan hambatan yang tidak sedikit karena kurangnya sumber daya manusia, sarana dan prasarana ynag tidak memadai sehingga terkendalanya proses administrasi pemerintahan. Terbukti dengan tidak tepat waktunya penyelesaian Rencana Pembangunan Jangka Menengah (RPJM) Nagari, penetapan Anggaran Pendapatan dan Belanja (APB) Nagari yang melebihi waktu yang telah ditentukan sehingga berakibat tidak terlaksananya kegiatan dan besarnya sisa lebih pagu anggaran tahun berjalan, Kondisi ini membuat tidak maksimalnya pelayanan publik dan pelayanan aparatur oleh pemerintah nagari. Camat sesuai dengan tugas dan kewenangan telah berupaya meminimalisir supaya hal ini tidak terjadi terus menerus melalui kegiatan pemberdayaan aparatur pemerintahan nagari yang dianggarkan dalam Daftar Penggunaan Anggaran di Kecamatan serta memonitor dan mengevaluasi jalannya pemerintahan nagari. Masalah timbul karena kurangnya kesiapan dan keinginan aparatur pemerintahan nagari untuk melaksanakan tugas yang menuntut tertib administrasi, tertib pengelolaan anggaran Sesuai 
Peraturan Menteri Dalam Negeri Nomor 114 tahun 2014 pasal 37 ayat (3) menyatakan bahwa Anggaran Pendapatan Belanja Nagari (APB) Nagari tahun berikutnya ditetapkan pada 31 Desember tahun berjalan. Kenyataannya semua nagari yang ada di Kecamatan Suliki ditahun 2018,2019 maupun ditahun 2020 Anggaran Pendapatan Belanja Nagarinya ditetapkan pada tahun Anggaran Pendapatan Belanja Nagari tersebut dilaksanakan. Hal ini berakibat terlambatnya pelaksanaan kegiatan yang bersumber dari dana desa. Camat sesuai dengan tugas dalam membina dan mengawasi penyelenggaraan kegiatan nagari harus terus berupaya supaya pemerintahan nagari berjalan sesuai dengan ketentuan perundang-undangan yang berlaku

Berdasarkan latar belakang pemikiran di atas, permasalahan yang menjadi kajian penulis dalam tulisan ilmiah ini adalah:

1. Bagaimanakah pelaksanaan kewenangan Camat dalam pemberdayaan pemerintahan nagari di Kecamatan Suliki Kabupaten Lima Puluh Kota?

2. Bagaimanakah kendala yang dihadapi dalam pemberdayaan pemerintahan Nagari di Kecamatan Suliki Kabupaten Lima Puluh Kota?

\section{METODE PENELITIAN}

Penelitian ini adalah penelitian yang bersifat deskriptif analitis, yaitu merupakan penelitian yang berusaha menggambarkan fakta yang berkaitan dengan kewenangan Camat dalam pemberdayaan pemerintahan nagari di Kecamatan Suliki. Data yang digunakan adalah data sekunder sebagai data utama dan data primer sebagai data pendukung, yang dikumpulkan melalui studi kepustakaan dan studi lapangan dengan teknik wawancara. Data tersebut kemudian dianalisis secara kualitatif dan disajikan dalam bentuk deskriptif kualitatif

\section{HASIL DAN PEMBAHASAN}

\section{Kewenangan Camat dalam Pemberdayaan Pemerintahan Nagari di Kecamatan Suliki} Kabupaten Lima Puluh Kota

\section{Evaluasi rancangan Peraturan Nagari tentang RAPB Nagari}

Bahwa untuk melaksanakan ketentuan pasal 89 Peraturan Pemerintah Republik Indonesia tentang peraturan pelaksanaan Undang-Undang Nomor 6 Tahun 2014 tentang Desa telah ditetapkan Peraturan Menteri Dalam Negeri Republik Indonesia Nomor 111 tahun 2014 tentang Pedoman Teknis Peraturan di Desa. Kewenangan Camat Suliki untuk mengevaluasi RAPB Nagari yang diajukan oleh Wali Nagari setelah disepakati bersama Badan Permusyawaratan Nagari (BAMUS). Wali Nagari bersama BAMUS wajib menindaklanjuti hasil evaluasi yang dilakukan oleh Camat sebelum disampaikan kepada Badan Keuangan Kabupaten Lima Puluh Kota. Evaluasi rancangan Peraturan Nagari tentang APB Nagari dilakukan oleh Camat Suliki berdasarkan kewenangan yang didelegasikan oleh Bupati Lima Puluh Kota melalui Peraturan Bupati Lima Puluh Kota Nomor 13 tahun 2018 tentang pendelegasian kewenangan Bupati dalam evaluasi rancangan peraturan nagari tentang anggaran pendapatan dan belanja nagari dan rancangan peraturan nagari tentang anggaran pendapatan dan belanja nagari perubahan kepada Camat. Evaluasi Rancangan Peraturan 
Nagari tentang APB Nagari dan Rancangan Peraturan Nagari tentang APB Nagari Perubahan merupakan tanggung jawab Camat sebagai penerima tugas delegasi. Evaluasi Rancangan Peraturan Nagari tentang APB Nagari dan Rancangan Peraturan Nagari tentang APB Nagari Perubahan disampaikan oleh Camat kepada Wali Nagari untuk diperbaiki sesuai dengan hasil evaluasi terkait penetapan skala prioritas maupun batas pengalokasian penggunaan anggaran untuk kegiatan. Setelah hasil evaluasi disampaikan oleh Camat Suliki ke Wali Nagari dan diperbaiki barulah Camat Suliki mengeluarkan Surat Keputusan tentang penetapan alokasi anggaran bagi nagari sudah sesuai dengan ketentuan.

\section{Fasilitasi dan koordinasi penyusunan laporan Wali Nagari}

\section{a. Laporan Wali Nagari}

Permendagri Nomor 46 Tahun 2016 tentang Laporan Kepala Desa. Wali Nagari wajib menyampaikan Laporan Penyelenggaraan Pemerintahan Nagari kepada Bupati melalui Camat sebagai bentuk implementasi prinsip akuntabilitas pengelolaan keuangan di nagari. Dokumen ini adalah refleksi dari bobot pencapaian kegiatan pemerintahan nagari selama 1 (satu) tahun anggaran. Camat Suliki sudah melakukan fasilitasi penyampaian laporan penyelenggaraan pemerintahan nagari dengan melakukan evaluasi laporan Wali Nagari se Kecamatan Suliki seperti Laporan Penyelenggaraan Pemerintahan Nagari akhir tahun, Laporan Penyelenggaraan Pemerintahan Nagari akhir jabatan. Laporan penyelenggaraan Pemerintahan Nagari akhir tahun digunakan untuk bahan evaluasi, dan berdasarkan evaluasi tersebut maka Bupati menetapkan kebijakan baik berupa pembinaan maupun pengawasan.

b. Evaluasi perkembangan nagari

Untuk melakukan evaluasi perkembangan nagari di Kecamatan Suliki sesuai dengan peraturan Menteri Dalam Negeri Nomor 81 tahun 2015 tentang evaluasi perkembangan desa dan kelurahan. Camat Suliki sudah melakukan tugas sesuai dengan kewenangan untuk mengevaluasi perkembangan nagari yang dimulai dari evaluasi diri yang dilakukan oleh pemerintah nagari. Evaluasi perkembangan nagari yang dilakukan oleh Camat Suliki berupa evaluasi bidang pemerintahan, bidang kewilayahan dan bidang kemasyarakatan. Evaluasi perkembangan nagari dilaksanakan oleh Camat pada bulan Februari sampai dengan Bulan Maret dengan melakukan analisis dan validasi berdasarkan hasil evaluasi diri untuk mendapatkan kesesuaian data

Berdasarkan peraturan Bupati Lima Puluh Kota Nomor 8 Tahun 2016 tentang Evaluasi Perkembangan Nagari pasal 14 ayat (2) menyatakan bahwa Camat melakukan penilaian hasil evaluasi diri yang sudah sesuai. Dalam hal terjadi ketidaksesuaian data, Camat Suliki melakukan peninjauan dan klarifikasi ke Nagari untuk menguji kesesuaian data. Penilaian hasil diri yang sudah sesuai merupakan penilaian hasil perkembangan nagari dalam kategori :

1) Nagari cepat berkembang

2) Nagari berkembang

3) Nagari kurang berkembang

Berdasarkan laporan hasil penilaian dan pemringkatan nagari, terhadap nagari kurang berkembang dilakukan Camat melakukan pembinaan dan pemberdayaan secara khusus. 


\section{Pengkoordinasian penyusunan Peraturan Nagari}

Bahwa untuk melaksanakan ketentuan pasal 89 Peraturan Pemerintah Republik Indonesia tentang peraturan pelaksanaan Undang-Undang Nomor 6 Tahun 2014 tentang Desa telah ditetapkan Peraturan Menteri Dalam Negeri Republik Indonesia Nomor 111 tahun 2014 tentang Pedoman Teknis Peraturan di Desa. Dalam ketentuan umum dijelaskan bahwa peraturan di desa/nagari adalah peraturan yang meliputi peraturan nagari, peraturan bersama Wali Nagari dan peraturan Wali Nagari . Kewenangan Camat Suliki adalah memfasilitasi penyusunan peraturan Nagari, peraturan bersama Wali Nagari dan sudah dilaksanakan dengan melakukan bimbingan teknis tata cara pembuatan peraturan di nagari.

Peraturan Nagari disusun oleh Wali Nagari bersama Badan Permusyawaratan Nagari. Setelah Peraturan Nagari disetujui oleh Badan Permusyawaratan Nagari, ditandatangani oleh Wali Nagari disampaikan kepada Bupati dan untuk pemberlakuannya tidak diperlukan pengesahan dari Bupati. Untuk melaksanakan peraturan nagari dan peraturan perundangundangan yang berlaku di nagari tersebut, Wali Nagari dapat membuat Keputusan Wali Nagari . Dalam pembuatan dan penetapan peraturan nagari, Camat berperan sebagai pembina teknis. Hasil wawancara penulis dengan Usman Soid,S.Sos " Camat membantu secara teknis penyusunan peraturan nagari agar tidak berbeda dan tidak bertentangan dengan peraturan di atasnya". Begitu juga dengan hasil wawancara penulis dengan Gusfialdi bahwa " pemerintah nagari meminta petunjuk cara-cara penulisan peraturan nagari kepada Camat, setelah penyusunan peraturan nagari selesai, pemerintah nagari memberikan peraturan nagari tersebut ke Camat untuk diperiksa sebelum diserahkan ke Bagian Hukum di Kabupaten.

\section{Fasilitasi penyusunan organisasi dan tata kerja pemerintah nagari}

Peraturan Menteri Dalam Negeri No 84 tahun 2015 tentang susunan organisasi dan tata kerja pemerintah desa dalam ketentuan umum dijelaskan bahwa struktur organisasi dan tata kerja pemerintah nagari adalah satu sistem dalam kelembagaan dalam pengaturan tugas dan fungsi serta hubungan kerja. Penataan organisasi dan tata kerja pemerintah nagari sudah dilaksanakan di Kecamatan Suliki sesuai dengan peraturan Bupati Lima Puluh Kota Nomor 61 tahun 2018 tentang pedoman penyusunan struktur organisasi dan tata kerja pemerintah nagari.

Camat Suliki sudah melaksanakan kewenangan dalam penataan struktur organisasi dan tata kerja pemerintah nagari sesuai dengan peraturan Bupati Lima Puluh Kota Nomor 61 Tahun 2018 sehingga sudah ada pemringkatan nagari sesuai dengan perkembangannya yaitu :

a. Nagari Swasembada wajib memiliki 3 (tiga) urusan dan 3 (tiga) seksi

b. Nagari Swakarya dapat memiliki 3 (tiga) urusan dan 3 (tiga) seksi

c. Nagari Swadaya memiliki 2 (dua) urusan dan 2 (dua) seksi.

\section{Fasilitasi pengelolaan keuangan nagari dan pengelolaan aset nagari}

a. Fasilitasi pengelolaan keuangan nagari

Peraturan Menteri Dalam Negeri Nomor 113 tahun 2014 tentang Pedoman Pengelolaan Keuangan Desa. Dalam ketentuan umum dijelaskan bahwa keuangan desa adalah semua hak dan kewajiban nagari yang dapat dinilai dengan uang serta segala sesuatu berupa uang dan 
barang yang berhubungan dengan pelaksanaan hak dan kewajiban nagari. Kewenangan Camat dalam pengelolaan keuangan nagari adalah dalam mengevaluasi RAPBN Nagari yang telah dibahas dan disepakati dengan BAMUS Nagari. Pengaturan kekayaan nagari diatur oleh Keputusan Wali Nagari atas persetujuan Badan Permusyawaratan Nagari. Setiap menjelang tahun anggaran baru Bupati memberikan Pedoman Penyusunan Pendapatan dan Belanja Nagari kepada pemerintahan nagari dan Badan Permusyawaratan Nagari. Wali Nagari bersama Badan Permusyawaratan Nagari menetapkan Anggaran Pendapatan dan Belanja Nagari setiap tahun dengan Peraturan Nagari, selambat-lambatnya satu bulan setelah ditetapkannya APBD Kabupaten.

Dalam hal ini konsultasi secara teknis pembuatan APB Nagari dilaksanakan oleh pemerintahan nagari dengan Camat, tetapi Camat tidak berhak mengatur isi dari APB Nagari ini. Pengeluaran dan pemasukan diatur oleh Nagari sendiri. Hal ini tercermin dari hasil wawancara penulis dengan Yefriandi bahwa " Kami meminta kepada Camat untuk membantu tata cara dan konsultasi apakah Anggaran Pendapatan dan Belanja Nagari ini benar, sebelum di laporkan ke pihak Kabupaten Lima Puluh Kota Tetapi data-data dalam Anggaran Pendapatan dan Belanja Nagari diatur dan disetujui oleh Wali Nagari bersama Badan Permusyawaratan Nagari. Setelah Anggaran Pendapatan dan Belanja Nagari terbentuk pemerintah nagari mengajukan Anggaran Pendapatan dan Belanja Nagarinya ke kabupaten melalui Camat.

b. Fasilitasi pengelolaan aset nagari

Peraturan Menteri Dalam Negeri Nomor 1 tahun 2016 tentang pengelolaan aset desa/nagari. Aset desa/nagari adalah barang milik desa/nagari yang berasal dari kekayaan asli milik desa/nagari dibeli atau diperoleh atas beban Anggaran Pendapatan Belanja Nagari. Pengelolaan aset nagari dan dimulai dari perencanaan, pengadaan, penggunaan, pemanfaatan, pengamanan, pemeliharaan dan pengghapusan. Kewenangan Camat Suliki dalam pengelolaan aset nagari dilakukan dalam bentuk fasilitasi pembentukan tim pengelola aset nagari serta mengupayakan adanya kesepakatan antar nagari dalam mengelola aset bersama antar nagari.

Camat dalam hal ini tidak berhak mengatur dan mengganggu sumber-sumber kekayaan yang menjadi hak nagari. Camat hanya bertugas mengawasi penggunaan sumber-sumber kekayaan nagari dan menganjurkan kepada nagari untuk mengelola kekayaan yang ada di nagari."Apabila terjadi sengketa tentang kekayaan/aset yang ada dinagari, dan tidak dapat terselesaikan oleh pemerintah nagari, Camat harus membantu menyelesaikannya sengketa tersebut".

\section{Kendala dan upaya yang dilakukan Camat Dalam Pemberdayaan Pemerintahan Nagari di Kecamatan Suliki Kabupaten Lima Puluh Kota}

Pelaksanaan pemberdayaan pemerintahan nagari yang dilakukan oleh Camat Suliki mengalami kendala-kendala, kendala tersebut antara lain : 


\section{Batas Kewenangan.}

Kendala yang dihadapi Camat Suliki dalam melaksanakan pemberdayaan pemerintahan nagari karena belum adanya komitmen yang jelas dari pelimpahan kewenangan yang didelegasikan kepada Camat. Sehingga pelaksanaan kewenangan tersebut belum sesuai dengan harapan. Pelimpahan kewenangan dari Bupati kepada Camat perlu ditelaah dan dikaji lebih lanjut dalam bentuk evaluasi terhadap kewenangan yang dilimpahkan.

Selama ini kewenangan yang dilimpahkan masih bersifat umum dan tidak mempunyai aturan yang, jelas dan mengikat. Sehingga ada keraguan bagi Camat untuk menafsirkan dan menindaklanjuti kewenangan tersebut. Dalam tataran praktis, pendelegasian kewenangan dari Bupati kepada Camat dalam rangka pemberdayaan pemerintahan nagari perlu dilakukan penilaian terhadap tugas pokok dan fungsi Camat serta kewenangan Nagari sebagai suatu sistem pemerintahan. Sehingga dapat dilakukan inventarisasi kemungkinan kewenangan yang bisa dan dapat dilimpahkan kepada Camat sesuai dengan ruang lingkup kewilayahan. Hal ini dilakukan karena Kecamatan selaku organisasi perangkat daerah, memiliki otorisasi hak kewilayahan yang tidak dimiliki oleh organisasi perangkat daerah lainnya. Pelimpahan kewenangan tidak akan mengurangi peran dan fungsi Dinas/Badan, melainkan peran dan fungsi tersebut akan berjalan lebih efisien.

Kecamatan sebagai perangkat daerah mempunyai tugas yang sama dengan Dinas dan Badan dalam pembinaan, pemberdayaan dan pengawasan pemerintahan nagari. Tetapi pada kenyataannya pemerintah Kabupaten Lima Puluh kota lebih mengedepankan lembaga sektoral (Dinas) dan lembaga strategis daerah (badan). Akibat Kecamatan tidak mempunyai tugas dan wewenang yang jelas, sehingga anggarannya pun menjadi tidak jelas ditengah beban kerja yang mengalami peningkatan karena berbagai persoalan yang dihadapi oleh pemerintah nagari.

\section{Kurangnya koordinasi Kecamatan dengan Pemerintah Nagari.}

Dalam Undang-Undang Nomor 6 Tahun 2014 tentang Desa , Wali Nagari tidak lagi bertanggung jawab kepada Camat. Dalam melaksanakan tugas dan kewajibannya Wali Nagari bertanggung jawab kepada rakyatnya melalui pelaksanaan tugas pada Bupati. Penerapan Undang-Undang 23 Tahun 2014 tentang Pemerintah Daerah memberikan perubahan peranan Kecamatan secara struktural dan hirarki terhadap penyelenggaraan pemerintahan Nagari. Undang-Undang 6 tahun 2014 telah menempatkan kedudukan pemerintah nagari pada saat ini terhadap Kecamatan adalah independen dan koordinat.

Kedudukan nagari yang independen dan koordinat ini terhadap Kecamatan menyebabkan Nagari beranggapan bahwa mereka tidak bisa lagi diperintah dan dikendalikan oleh Kecamatan dan apabila ada persoalan maka mereka lebih cenderung untuk langsung mengkonsultasikannya dengan pihak kabupaten. Hal ini dibenarkan Usman Soid,S.Sos yang mengatakan bahwa sekarang Wali Nagari kalau ada permasalahan-permasalahan dinagarinya kebanyakan Wali Nagari langsung menyampaikan persoalan-persoalannya kepada kabupaten tanpa memberi tahukan terlebih dahulu kepada Camat. 
Hal senada juga disampaikan oleh Jaswir bahwa pada awal diberlakukannya UndangUndang Nomor 6 tahun 2014, pemerintah nagari sulit untuk diajak berkoordinasi dan langsung berurusan kekabupaten tapi secara berangsur angsur hal tersebut dapat diatasi.

Kondisi seperti di atas, menyulitkan bagi Camat untuk membina kerjasama dengan pemerintah nagari. Padahal, Peraturan Bupati Lima Puluh Kota Nomor 72 tahun 2016 Tentang Kedudukan, Susunan Organisasi, Tugas dan Fungsi serta Tata Kerja Kecamatan mewenangkan Camat untuk membina, mengawasi dan memberdayakan pemerintahan nagari. Kerja sama ini sangat perlu dilakukan dalam rangka memberikan pelayanan kepada masyarakat.

\section{PENUTUP}

Berdasarkan hasil penelitian penulis terhadap kewenangan Camat dalam pemberdayaaan pemerintahan Nagari di Kecamatan Suliki Kabupaten Lima Puluh Kota, diperoleh kesimpulan bahwa kewenangan Camat yang dilaksanakan dalam pemberdayaan pemerintahan Nagari di Kecamatan Suliki meliputi : fasilitasi kepada Nagari untuk melaksanakan penyusunan/penetapan organisasi perangkat nagari, menetapkan perangkat dan memfasilitasi pengangkatan Wali Nagari, Konsultasi teknis pembuatan APBNagari, mengawasi penggunaan sumber-sumber kekayaan nagari, mengawasi dan menfasilitasi pembentukan Badan Permusyawaratan Nagari, melakukan pembinaan teknis dalam pembuatan dan penetapan peraturan nagari, menjaga keamanan dan ketertiban serta fasilitasi kerjasama antar nagari.

Sedangkan kendala yang dihadapi Camat dalam Pemberdayaan Pemerintahan Nagari di Kecamatan Suliki Kabupaten Lima Puluh Kota adalah terbatas dan tidak jelasnya kewenangan yang di limpahkan kepada Camat disertai penganggaran yang minim serta kurangnya koordinasi pemerintah nagari dengan Kecamatan.

Upaya yang dilakukan Camat Suliki untuk mengatasi kendala yang dihadapi adalah: melakukan pemberdayaan peningkatan kemampuan perangkat nagari dalam penyelenggaraan pemerintahan melalui pelaksanaan bimbingan teknis bagi aparatur pemerintahan nagari serta menjalin koordinasi yang lebih intensif dengan pemerintahan nagari.

\section{DAFTAR PUSTAKA}

Bagir Manan, Sistem Peradilan Yang Berwibawa, FH UII Press, Yogyakarta, 2007

Hufron dan Sofyan Hadi, Ilmu Negara Kontemporer, Laksbang Grafika, Yogyakarta, 2016

Undang-Undang Dasar Negara Republik Indonesia Tahun 1945

Undang-Undang Nomor 5 tahun 1974 tentang Pokok-pokok Pemerintahan di Daerah

Undang-Undang Nomor 22 tahun 1999 tentang Pemerintahan Daerah

Undang-Undang Nomor 32 tahun 2004 tentang Pemerintahan Daerah

Undang-Undang Nomor 6 tahun 2014 tentang Desa

Undang-Undang Nomor 23 tahun 2014 tentang Pemerintahan Daerah 
Peraturan Pemerintah Republik Indonesia Nomor 8 Tahun 2003 tentang Struktur Organisasi dan Tata Kerja Perangkat Daerah

Peraturan Pemerintah Republik Indonesia Nomor 19 Tahun 2008 tentang Kecamatan

Peraturan Pemerintah Republik Indonesia Nomor 43 Tahun 2014 tentang Peraturan Pelaksanaan Undang-Undang Nomor 6 Tahun 2014

Peraturan Pemerintah Republik Indonesia Nomor 18 Tahun 2017 tentang Perangkat Daerah

Peraturan Pemerintah Republik Indonesia Nomor 17 tahun 2018 tentang Kecamatan

Peraturan Menteri Dalam Negeri Republik Indonesia Nomor 111 tahun 2014 tentang Pedoman Teknis Peraturan di Desa

Peraturan Menteri Dalam Negeri Republik Indonesia Nomor 112 tahun 2014 tentang Pemilihan Kepala Desa

Peraturan Menteri Dalam Negeri Republik Indonesia Nomor 113 tahun 2014 tentang Pedoman Pengelolaan Keuangan Desa

Peraturan Menteri Dalam Negeri Republik Indonesia Nomor 81 tahun 2015 tentang Evaluasi Perkembangan Desa Dan Kelurahan

Peraturan Menteri Dalam Negeri Republik Indonesia Nomor 82 tahun 2015 tentang Pengangkatan dan Pemberhentian Kepala Desa

Peraturan Menteri Dalam Negeri Republik Indonesia Nomor 83 tahun 2015 tentang Pengangkatan dan Pemberhentian Perangkat Desa

Peraturan Menteri Dalam Negeri Republik Indonesia Nomor 84 tahun 2015 tentang Susunan Organisasi dan Tata Kerja Pemerintah Desa

Peraturan Menteri Dalam Negeri Republik Indonesia Nomor 1 tahun 2016 tentang Pengelolaan Aset Desa

Peraturan Menteri Dalam Negeri Republik Indonesia Nomor 44 tahun 2016 tentang Kewenangan Desa

Peraturan Menteri Dalam Negeri Republik Indonesia Nomor 46 tahun 2016 tentang Laporan Kepala Desa

Keputusan Menteri Dalam Negeri Nomor 158 tahun 2004 tentang Pedoman Organisasi Kecamatan

Peraturan Daerah Provinsi Sumatera Barat Nomor 2 Tahun 2007 tentang Pemerintahan Nagari

Peraturan Daerah Kabupaten Lima Puluh Kota Nomor 1 tahun 2018 tentang Nagari

Peraturan Bupati Lima Puluh Kota Nomor 27 Tahun 2002 tentang Kewenangan Camat dalam Kabupaten Lima Puluh Kota

Peraturan Bupati Lima Puluh Kota Nomor 15 Tahun 2016 tentang Pembentukan dan Susunan Perangkat Daerah

Peraturan Bupati Lima Puluh Kota Nomor 72 Tahun 2016 tentang Kedudukan Susunan Organisasi, Tugas dan Fungsi serta Tata Kerja kecamatan 
Peraturan Bupati Lima Puluh Kota Nomor 13 Tahun 2018 tentang Pendelegasian Kewenangan Dalam Evaluasi Rancangan Peraturan Nagari Tentang Anggaran Pendapatan dan Belanja Nagari dan Rancangan Peraturan Nagari Tentang Anggaran Pendapatan dan Belanja Nagari Perubahan kepada Camat

Peraturan Bupati Lima Puluh Kota Nomor 61 Tahun 2018 tentang Pedoman Penyusunan Struktur Organisasi dan Tata Kerja Pemerintah Nagari

Peraturan Bupati Lima Puluh Kota Nomor 69 Tahun 2018 tentang Daftar Kewenangan Nagari Berdasarkan Hak Asal Usul dan Kewenangan Lokal Berskala Nagari. 